\title{
FURTHER RECORDS AND DESCRIPTIONS OF , BACTRA SPECIES (LEPIDOPTERA, TORTRICIDAE), CHIEFLY IN Dr. H. G. AMSEL COLLECTION
}

by

\author{
A. DIAKONOFF \\ (Rijksmuseum van Natuurlijke Historie, Leiden)
}

The present short paper forms a continuation of my partial revision of certain species of the genus Bactra (Zool. Verhand., no. 29, 1956). It is chiefly based on a revision of the entire material of Bactra in the collection of the well-known specialist of Microlepidoptera, Dr. H. G. AMSEL, Karlsruhe, Germany; along with the new material of the genus from Irak, and that from Afghanistan, of the German Afghanistan Expedition 1956, collected by Dr. AMsez himself and entrusted to me for identification. Besides, interesting material was received from Mr. Toshuo OKu, Sapporo, Japan, and from some other sources. The author gratefully acknowledges the kind help of the senders, and their permission to retain certain duplicates for the collection of the Leiden Museum.

Since the publication of my above mentioned paper a few errors were detected and some alterations became necessary. They will be found below, together with descriptions of five new species and one sub- species, and records or notes on some 15 already known species, with five new synonyms.

Continued study revealed to be gratifying, as the genus Bactra more and more appears to represent a very attractive field for taxonomic studies, chiefly due to the clear-cut genital characters of the two sexes. In the males the shape and the minor details of the armature of the valva may vary slightly. But the specific rigidity of the genital characters in the females is simply astonishing! These characters are extremely useful for the descrimination of the species. There seems to be no end to the specific variety within the genus. The division of Bactra in four subgenera (1956) proved to be natural and useful, at least with the three of the four, the New Zealand subgenus Noteraula remaining monobasic and therefore little known.

The author intends a world-wide revision of the genus Bactra. Any material for re-examination or identification will be received with gratitude.

\section{Bactra (Bactra) lanceolana (Hübner 1796)}

Tortrix lanceolana Hübner 1796, Samml. europ. Schmett., vol. 7, Tortr., t. 13, fig. 80.

Bactra (Aphelia) fumosana Kennel 1900, Iris, vol. 13, p. 263. Syn. nov.

Bactra fumosana, Kennel 1910, Palaearkt. Tortr., p. 472473, t. 18, fig. 73a. - Rebel, in Staudinger \& Rebel 1901, Catal. Lep. Pal. Faun., vol. 2, p. 113.

Bactra (Bactra) fumosana, Diakonoff 1956, Zool. Verhand., no. 29 , p. 16 , fig. 16 (gen. $q$ type fig.).

Distribution. Palaearctic region.

Iran, Shiraz, 15.VII.1940, 1 \%, gen. no. 2856; no date, probably also Shiraz, $2 \delta$, gen. nos. 2849, 2853. Barfkhanen, 9-12.000 feet, IV.1940, $1 \hat{\delta}$, gen. no. 2854 (E. P. WiLtshire leg., Amsel Coll.). $3 \delta$ กิ, 1 q.
Afghanistan, Herat, 970 m, 25.IV.1956 (H. G. AMSEL), $7 \delta$, gen. nos. 2515, 2729, 2730, 2732, 2741, 2742,$2744 ; 8 \hat{o}$, nos. 2794-2801; $9 \hat{\partial}$, nos. 2806-

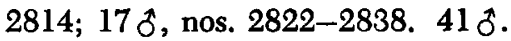

Furthermore, identification of the following material was confirmed. Sardinia, Isili, 20.VII.1936 (H. G. AMSEL), 1 $\delta$, gen. no. 2720; Porto Santoru, 18.VI.1936 (H. G. AMSEL), $2 \delta$, gen. nos. G.U. 90 and $95 ; 1$, gen. no. G.U. 101 (Ams.); Anitro, 6.VI.1934, 1 î, gen. no. G.U. 91; Tempio, 18.IX.1934, 1 ô, gen. no. G.U. 98 (Predota leg., Schawerda Collection). Syria, Damascus, 27.VI.1950 (H. G. AMSEL), $1 \hat{\delta}$, gen. no. 2722. Iraq, Haj Omran, Rayat, 5000-6000 feet, 2-13.VI.1956, e coll. WIITSHIRE, 1 ठै, gen. no. G.U. 3372 (Ams.).

Bactra (Bactra) lanceolana (Hübner 1796) forma $q$ fumosana Kennel status nov. (Pl., fig. 3)

In my 1956 revision I was dubious about the status of "Bactra fumosana". At the time the unique speci- men and type available seemed to be rather distinct from lanceolana and I preferred to keep it separate, 
pending further evidence of additional material.

This evidence turned up sooner than I could have hoped, in the form of three specimens from Iran in the Amsel Collection, all females again. They were collected side by side with typical lanceolana, males and a female. After critical re-investigation of the genitalia I was satisfied that there are no reasons for maintaining fumosana as a separate species. In my opinion it is but a female form (not even a subspecies) of Bactra (B.) lanceolana.

The slight differences in the shape and in minor particulars of the sterigma appear somewhat exaggerated in the type specimen (cf. my Fig. 16, 1956) and represent the extreme of a moderate variation. At present I have intermediate specimens at hand, as, e.g., that with gen. no. 2775, illustrated on Pl., fig. 3. In this specimen the colliculum is dilated above, as in lanceolana (cf. my Figs. 12-13, 1956) and its ventral rim has a small spout, also as in that species; the characteristic punctulate field above the ostium (lamella postvaginalis) has also an intermediate shape; the deceiving folds $f$ of fumosana, giving it a peculiar aspect, are also present here, but are weak, etc.

It seems worth while to retain for the present KENNEL's name for this form.

Iran, Resht, Tabergourabe, 20.V.1955 (Fr. Schauffele), 1 \&, gen. no. 2775. Fars, Pireh Zan, 1000 feet, 4.X.1950, 1 \%, gen. no. 2851. Shiraz, 15.VII.1940, 1 \%, gen. no. 2855 (E. P. WiLtShiRE). 3 ㅇ.

\section{Bactra (Bactra) honesta Meyrick 1909 (Pl., fig. 1)}

Bactra honesta Meyrick 1909, J. Bombay Nat. Hist. Soc., vol. 19, p. 585 ( $\not ̊$, Assam). - Diakonoff 1950, Bull. Brit. Mus., Ent., vol. 1, p. 287, pl. 6, fig. 23, pl. 7, fig. 33 (lectotype select., gen. $\delta \hat{q} q$ fig.).

Distribution. India, Bengal.

The species is very close to lanceolana but decidedly distinct. In the British Museum (Natural History) where the type is preserved, I was allowed to remount the genitalia and to re-examine them closely; they are figured once more on Pl., fig. 1, with the valvae turned flat as much as possible. From this figure it is evident that the dorsal portion of the genitalia (uncus and socii) is exactly similar to that in lanceolana but the tegumen is much less robust and more similar to that in furfurana. Especially the valva is different, it is shorter, broad at base and distinctly pointed at the apex, while the sacculus is rather acutely prominent and triangular (left sacculus is broken in two).

\section{Bactra (Bactra) furfurana (Haworth 1811)}

Tortrix furfurana Haworth 1811, Lep. Brit., p. 466.

Distribution. Palaearctic region.

Iran, Fars, Sineh-Safid, ca. 6500 ft., 2.IX.1950 (E. P. Wiltshire), $1 \delta$, gen. no. 2852.

South West Afghanistan, Herat, $910 \mathrm{~m}, 5 . \mathrm{V}$. 1956 (H. G. AMSEL), 1 o, gen. no. 2731; Hilmend River, Darweshan, Registan Desert, 500 m, 18.V.
1957 (G. EberT), 1 $\delta$, gen. no. 2717; 1 \%, gen. no. 2746. East Afghanistan, Sarobi, $1100 \mathrm{~m}, 28 . \mathrm{VI}$. 1956 (H. G. AMSEL), 1 ơ, gen. no. 2727; 1 \%, no. 2739.

Spanish Morocco, Buhasen, $1000 \mathrm{~m}$ marsh, 9.VI.1954 (E. DE BRos), 1 ठ̀, gen. no. 2723.

All specimens in the AMSEL Collection.

\section{Bactra (Bactra) longinqua spec. nov. (Fig. 1)}

o $17 \mathrm{~mm}$. With a general appearance and markings of a lanceolana male, but with narrower wings and distinct genitalia.

Head, palpus, and thorax ochreous-whitish, terminal segment of palpus dark grey, slender, rather long, drooping. Abdomen ochreous-whitish. Fore wing narrow, sublanceolate, costa gently curved throughout; apex tolerably pointed, termen oblique, gently concave. Ochreous-whitish, markings pale ochreous- olive and dark fuscous. Basal fourth of costa with a series of minute dark marginal marks and a larger dot on extreme base; posterior part of costa with a series of dark fuscous longitudinal larger blotches, alternating with minute points; a few dark scales scattered over olive markings and along veins in disc; olive markings arranged in the usual pattern: a discal patch at $2 / 5$, connected with dorsum by a faint marbling; the same marbling indicating a basal patch; 


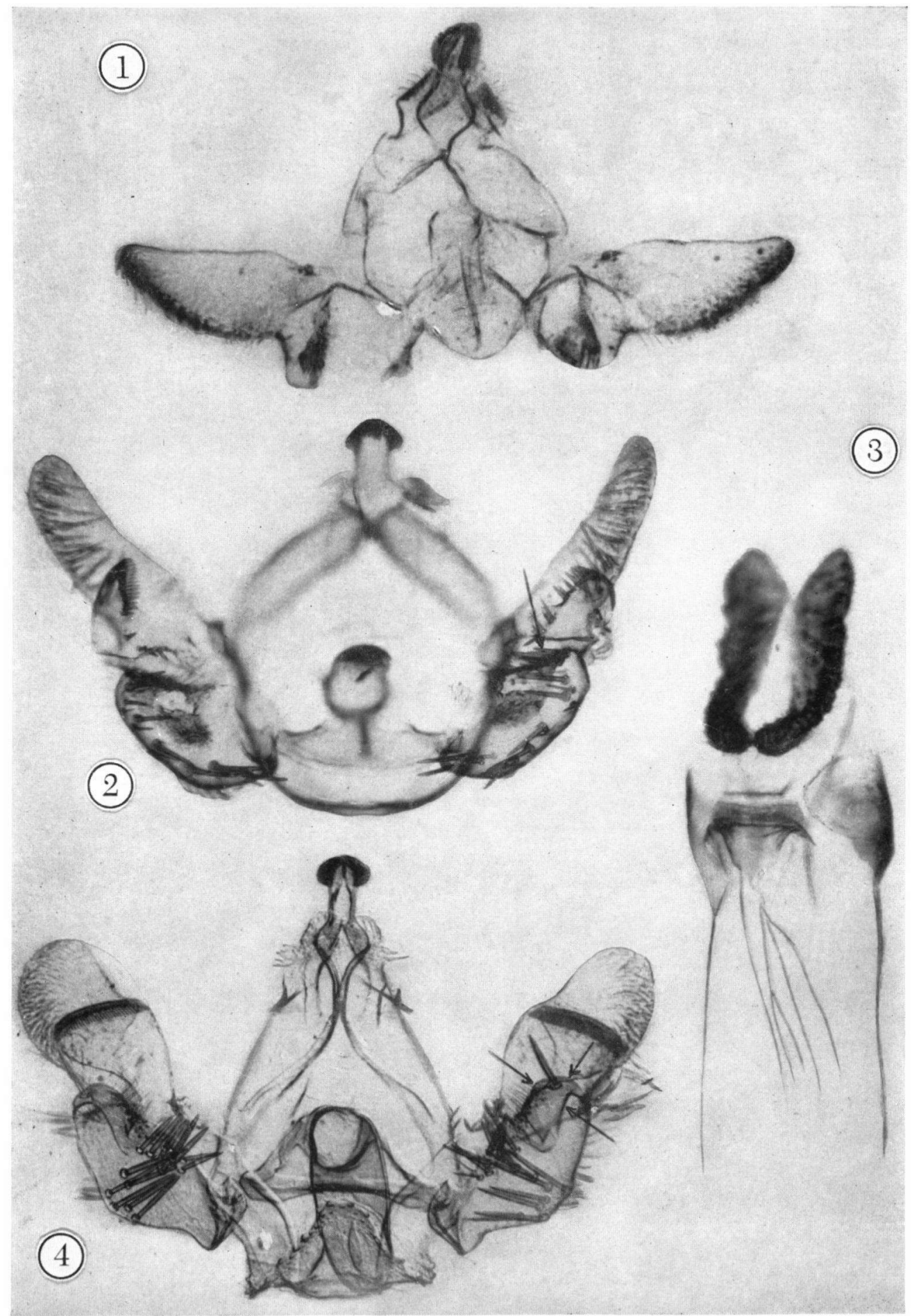

\section{EXPLANATION OF PLATE}

Fig. 1. Male genitalia of Bactra (Bactra) honesta Meyr. (holotype). Fig. 2. Male genitalia of B. (Chiloides) straminea Butl. forma ố iomolybda Meyr., holotype (gen. no. 9545 B.M., phot. no. 11509). Fig. 3. Female genitalia of B. (B.) lanceolana forma $ᄋ$ fumosana Kennel, Iran, no. 2775. Fig. 4. Male genitalia of B. (C.) truculenta Meyr., Pakistan, no, 2129. (Fig. 2, by the courtesy of the Trustees of the British Museum. Figs. 1, 3 and 4, author phot.) 

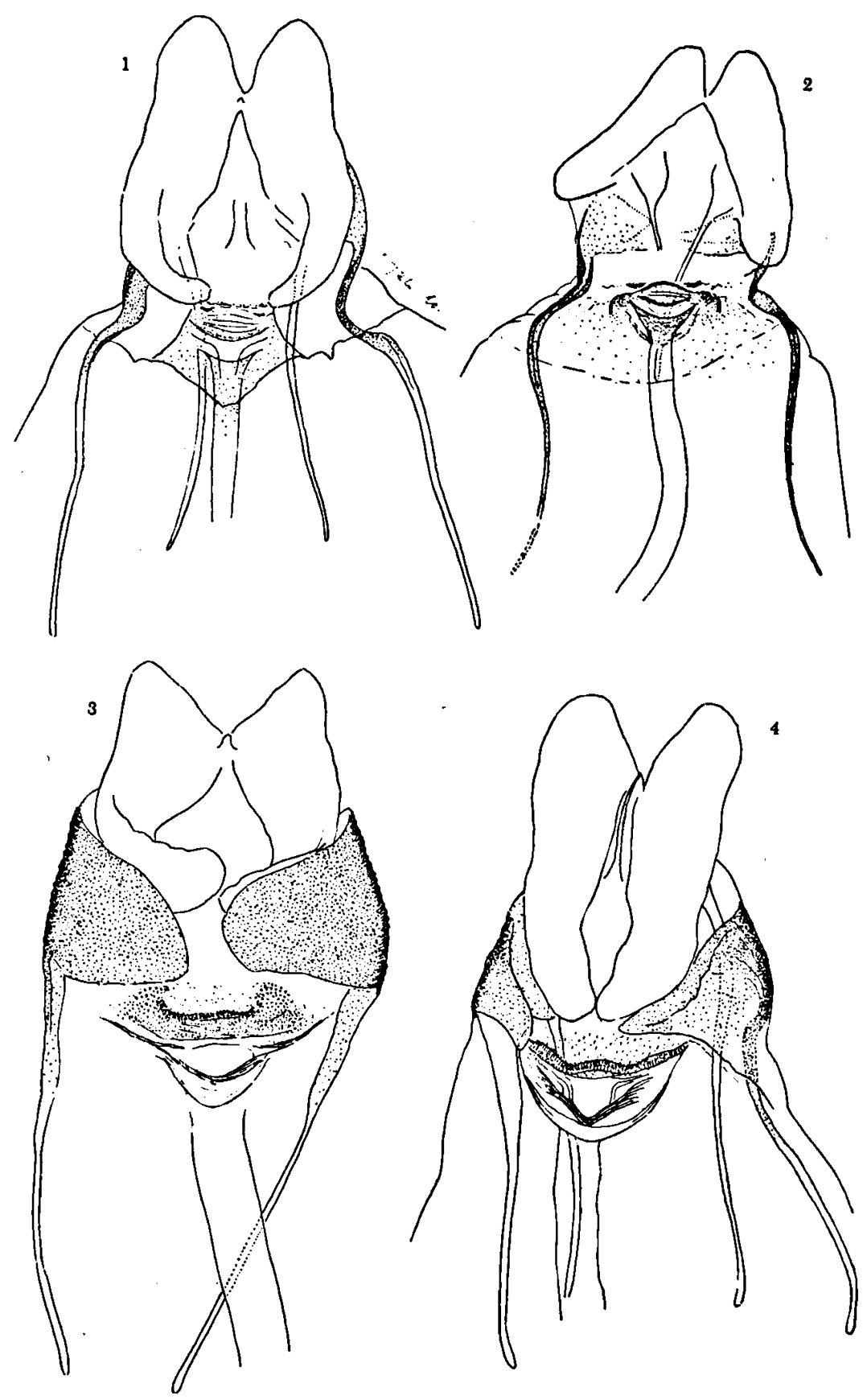

Figs. 1-4. Female genitalia of Bactra (Bactra). 1. longinqua spec. nov. (Afghanistan). 2. longinqua iranica subspec. nov. (Iran). 3. robustana Chr. (Sardinia). 4. amseli spec. nov. (Afghanistan)

an oblique streak from middle of costa to end of cell, ending there with an elegant crescentic mark; two erect blotches on dorsum, before and beyond preceding, outwardly and inwardly oblique, respectively; a longitudinal blotch in apex faintly connected by several lines with costa; a more or less interrupted terminal fascia, from below apex to tornus. Cilia ochreous-whitish, with a fine ochreous-olive subbasal line, cilia opposite apex mixed with dark fuscous.

Hind wing evenly and finely irrorated with fusc- 
ous, with a distinct purple gloss. Cilia ochreouswhitish, becoming deeper ochreous towards apex; a fuscous subbasal line.

Female genitalia (Text-fig. 1). Anapophyses strongly bent and sclerotized below base. Sterigma, or rather, the entire lamella postvaginalis shaped as a trapezoid, slightly sclerotized plate, in middle of which, a less sclerotized T-shaped portion, edged by slight folds; above this there is a series of longitudi- nal, not aciculate but slightly sclerotized folds, and above these on each side a small dark crescentic structure. Ostium bursae resembling that in furfurana but distinctly sclerotized. A small signum present. (Slide no. 2726, holotype).

East Afghanistan, Sarobi, 1100 m, 28.VI.1956 (H. G. AmSEL), 1 \%, holotype, gen. no. 2726. Unique. Apparently related to furfurana. Type in AMSEL Collection.

Bactra (Bactra) longinqua iranica subsp. nov. (Fig. 2)

† 11-17.5 mm (holotype $17.5 \mathrm{~mm}$ ). Head and thorax whitish. Antenna dark grey. Palpus whitish, median segment strongly expanded by roughish scales, faintly suffused with grey in middle externally, terminal segment slender, rather long, exposed, dark grey. Abdomen ochreous-whitish.

Fore wing elongate-sublanceolate, rather narrow, pointed, termen faintly sinuate, very oblique. Ochreous-white, irregularly marbled with vivid light ochreous, this colour tending to form a small basal patch, a submedian, and a median transverse band, and some indefinite marbling posteriorly; rather distinct costal blotches of variable size formed by this marbling; extreme edge of costa with minute dark marks formed by a few fine dark fuscous scales; ill-defined cloudy dark dotting along dorsum; a faint suffused longitudinal streak of brighter tawny-ochreous colour, extending from base to apex and occupying about $1 / 4$ of wing breadth; this streak interrupted between basal patch and the two transverse fasciae, and becoming darker, rather well-defined, tinged orange, and continuous; this portion of longitudinal fascia including a whitish ocellus on end of cell and strewn throughout, but more so posteriorly, with dark brown scales. Cilia whitish-ochreous, with a white basal line, followed by a faint darker ochreous subbasal line, cilia opposite apex tawny-ochreous, mixed with dark fuscous scales.

Hind wing glossy light fuscous-grey, darker towards apex. Cilia whitish-grey.
Paratype (imperfect) much smaller, with ground colour brighter white, markings duller but deeper, more olive-tawny tinged, and forming rather welldefined transverse bands, posterior of these angulate in middle; posterior third of wing entirely suffused with deeper olive-tawny, with anterior edge welldefined, triangularly incised; 3-4 oblique streaks of glossy whitish ground colour, originating from posterior part of costa, running across upper part of wing breadth. Otherwise similar to holotype.

Female genitalia (Text-fig. 2). Sterigma very similar to that of the nominate form but somewhat more sclerotized. The ventral rim of the cup of ostium bursae (lamella antevaginalis proper) stronger sclerotized and encircled ventrally by a series of fine hyaline folds; the hyaline lateral folds inside the ostium, as in the nominate form, absent, lamella postvaginalis similar, being a corrugated transverse-oval sclerite, but with stronger outward edges; small folds on each side and above this lamella, more distinct. The trapezoidal sclerite uniting the two lamellae, less distinct in the subspecies, rounded, with only the extreme angles indicated by short folds. (Slides nos. 2779, holotype, 2777, paratype).

South East Iran, Djiroft, Andar-Abad, 1-18.V. 1956 (W. RichteR), 1 \%, holotype, gen. no. 2779; Resht, Tabergourabe, VII-VIII.1954 (Fr. SchuufFeLE), 1 \&, paratype, gen. no. 2777. 2 \%. Holotype in AMSEL Collection.

\section{Bactra (Bactra) robustana (Christoph 1872) (Fig. 3)}

Aphelia robustana Christoph 1872, Horae Soc. Ent. Ross., vol. 9 , p. 13, t. 1, f. 10.

Bactra robustana, Rebel, in Staudinger \& Rebel 1901, Catal. Lep. Pal. Faun., vol. 2, p. 113. - Kennel 1910, Palaearkt. Tortr., p. 472, t. 18, f. 72. - Kloet \& Hincks 1945,
Checklist Brit. Ins., p. 124. - Vári 1951, Entom. Ber., vol. 13, p. 198. - Bentinck 1951, Tijdschr. v. Ent., vol. 94, p. 334. - Toll 1958, Annales Zool. Polon., vol. 17, p. 6572 , figs. 5-6, t. 2, f. 4, t. 3, f. 11.

Bactra scirpicolana Pierce 1935, Entomologist, vol. 68, p. 
148-149. Bentinck 1936, Tijdschr. v. Ent., vol. 79, p. XXVII. - L. c., p. 201. - Toll 1958, Annales Zool. Polon., vol. 17, p. 65 .

Grapholitha (Bactra) scirpicolana, Bentinck 1936, Tijdschr. v. Ent., vol. 79, p. 209.

Bactra griseana Djakonov 19£9, Rev. russe Entom., vol. 23 , p. 164, figs. 21-22.

Bactra grisea Diakonoff (nec Djakonov) 1956, Zool. Verhand. no. 29 , p. 13 (lapsus).

Distribution. Palaearctic region.

Sardinia, Teulada, 10.II.1934, 1 \&, gen. no. G.U. 103 (Ams) (H. G. AMSEL, in his collection).
South West Afghanistan, Herat, $970 \mathrm{~m}$, 25.IV. 1956 (H. G. AMSEL), I , gen. no. 2716. Iran, Resht, Tabergourabe, 20.V.1955 (Fr. Schauffele), 1 q, gen. no. 2772.

Identification of the following material was confirmed. Central Hungary, Dömsöd, 922.V.1923 (sic) (Sснмшт), 1 ठै, gen. no. 2802, 1 ठै, no. 2804; Izsák, 910.VII.1918 (SchmmT), 1 ठ̀, no. 2803. Germany, Borkum Island, e 1. 22.VI.1931, Scirp. marit., $1 \delta$, Gen. no. G.U. 89. Coll. BRINKMANN.

\section{Bactra (Bactra) amseli spec. nov. (Fig. 4)}

o 15-18 mm (holotype $18 \mathrm{~mm}$ ). Head and thorax pale ochreous; palpus strongly dilated by roughish scales above and beneath, concealing terminal segment (paratype); in holotype palpus worn, rather slender, with terminal segment short, exposed. Abdomen whitish-ochreous.

Fore wing narrow, elongate-lanceolate, moderately dilated, broadest at 3/4; costa little curved anteriorly, straight posteriorly, gently impressed along its third fourth, apex rather pointed, termen oblique, gently convex. Whitish-ochreous, finely dotted with pale tawny-ochreous, more than dorsal half of wing from base to apex evenly suffused with this colour; upper edge of this suffusion rather well-defined, posteriorly becoming concave, the suffusion running to apex and occupying its lower half; a deeper tawny suffusion in lower half of apex and along termen, becoming narrower and ill-defined downward; a couple of minute dark brown points scattered before termen (absent in left wing). Cilia whitish-ochreous, with a pale basal line, beyond this suffused with pale ochreoustawny, a small brownish dot opposite apex, on lower half of cilia.

Hind wing glossy grey-fuscous, becoming paler towards base, with a suggestion of a purplish gloss posteriorly. Cilia sordid whitish, with a pale fuscous subbasal line.

Female genitalia (Text-fig. 4). Eighth segment strongly sclerotized. Sterigma well-developed, shaped as a robust subtriangular plate, rounded below; ostium, a triangular opening, with a plicate and thickened lower edge. Lamella postvaginalis, a sinuate ridge, adorned with minute transverse strigulations. A small signum present. (Slides nos. 2734, holotype; 2778, paratype).

The paratype specimen has identical genitalia, but different markings: the fore wing is whitish, finely streaked with pale greyish-olive; a series of 4-5 pale fuscous oblique strigulae originating from costal dots along posterior fourth of costa; costal and dorsal edges throughout with a continuous series of dark fuscous points; a series of points before termen, distinct, clouded with faint fulvous suffusion.

South West Afghanistan, Hilmend River, 500 m, Darweshan, Registan Desert, 18.V.1957 (G. EBErT), 1 \%, holotype, gen. no. 2734. Iran, Resht, Tabergourabe, 20.V.1955 (Fr. Schauffele), 1 \%, paratype, gen. no. 2778. Holotype in Amsel Collection, paratype in the Leiden Museum.

Related to robustana.

Bactra (Bactra) festa spec. nov. (Figs. 9, 13, 14)

ô $15-16 \mathrm{~mm}$, $\& 15 \mathrm{~mm}$. Head and palpus pale ochreous; palpus moderate, median segment roughish towards apex below, terminal segment moderate, slender, exposed. Antenna pale grey. Thorax light ochreous-fuscous. Abdomen glossy pale silvery-grey.

Fore wing narrowly elongate, dilated, broadest at $4 / 5$, costa moderately bent at base, stronger bent at $4 / 5$, apex rounded-pointed, termen gently concave, oblique. Pale ochreous, suffused with ashy-grey, coarsely irrorated and dotted between markings, especially on basal half, with dark fuscous. Markings blackish-fuscous, suffusedly edged with tawny. Some eight transverse marks on costa, oblique and of various sizes, alternating with minute blackish transverse jots; on basal half of costa these marks short and unicolorous blackish; on posterior half the larger marks longitudinal, more suffused with tawny; penultimate mark giving rise to a tawny, slightly undulate line, 


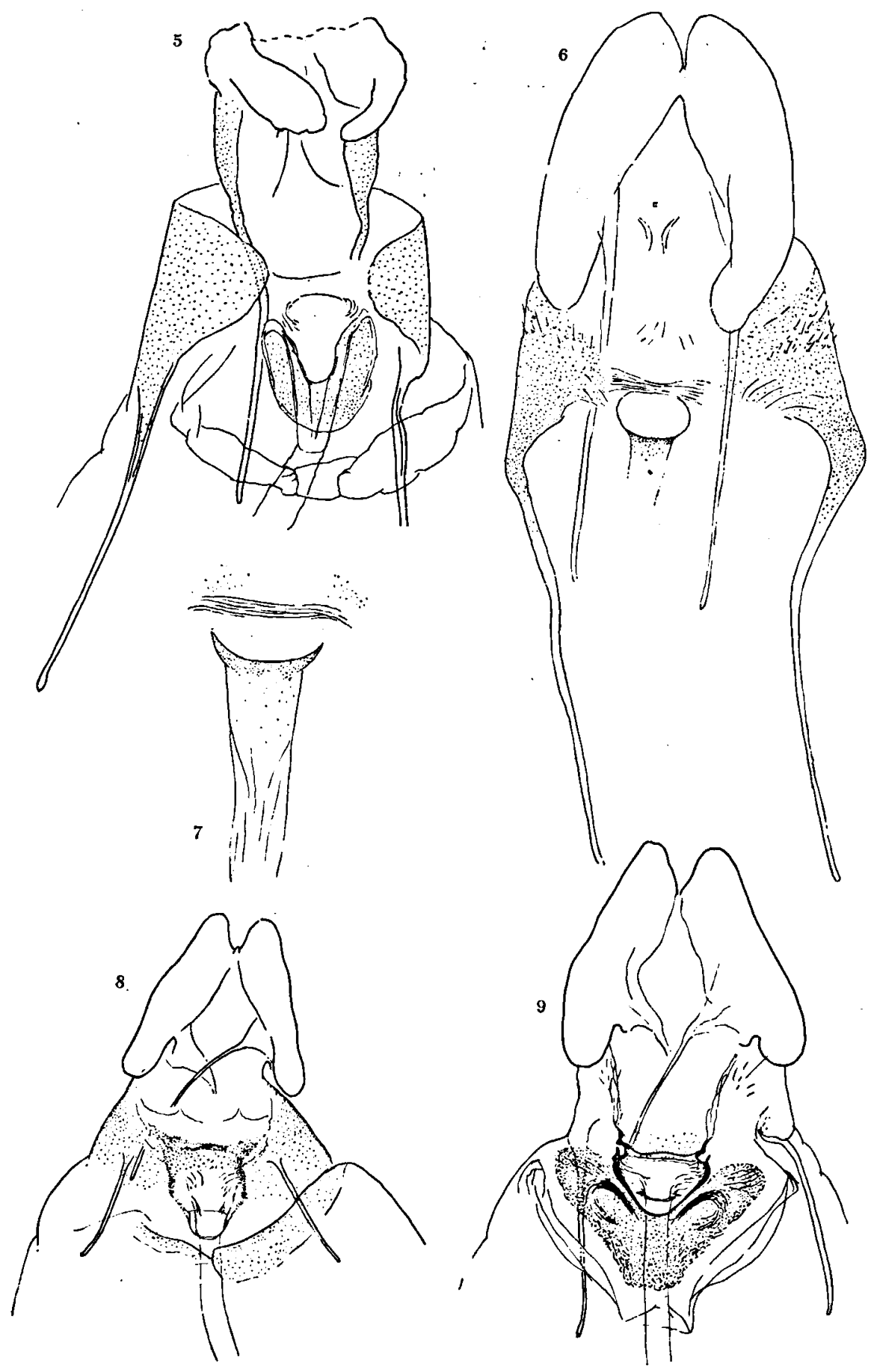

Figs. 5-9. Female genitalia of Bactra. 5. B. (Chiloides) telaviviana Amsel, holotype (Israel). 6. B. (B.) graminivora Meyrick, no. 2585 (E. Turkestan). 7. The same, ostium bursae stronger magnified, no. 2718. 8. B. (Nannobactra) leonina spec. nov., holotype (Pakistan). 9. B. (B.) festa spec. nov., allotype (Japan) 
obliquely crossing to upper part of termen, before termen abruptly bent downward; costal mark preceding this prolonged into a similar but shorter line, not reaching beyond vein 9; ultimate costal mark forming a small longitudinal blotch; a dark fuscous rounded spot in apex; a large slightly oblique Vshaped mark in disc, from middle of costa to lower angle of cell, thence rising towards apex but not reaching it; a series of semicrescentic, rather irregular marks along fold: a group together, beyond base, indicating edge of basal patch, a larger inwardsoblique blotch before $1 / 3$, and a smaller crescentic mark below and slightly before the top of the Vshaped mark, and two slender, interconnected marks forming a narrow zigzag between crescentic mark and termen; a small additional longitudinal mark on termen, between veins 4 and 5, connected with posterior arm of the V-shaped mark; fuscous small blotches irregularly extended along termen. Cilia pale ochreous, with a brownish subbasal, and a grey subapical, narrow lines; a fuscous suffused blotch opposite apex.

Hind wing rather dark grey, with a faint brown gloss. Cilia pale ochreous-greyish, with a faint subbasal fuscous line.

The female allotype (rather worn) is paler, more ochreous tinged, with dark markings ochreous-tawny instead of dark fuscous; an additional transverse strigula originating from the ultimate costal mark and running around apex to upper part of termen. Otherwise apparently similar to the holotype.

Male genitalia (Text-figs. 13, 14) resemble those of the Palaearctic robustana but are quite distinct, with the strong uncus longer, socii smaller. Especially characteristic is the large sacculus of the valva, being rather erect-oval, larger than in robustana but smaller than in loeligeri; the usual sheaf of spines $\mathrm{Spc}_{1}$ is situated more or less superficially and not in a rounded cavity, as in most species of this subgenus; cucullus rather slender and slightly more sinuate than in the two above mentioned species. As usual, the shape of the valva is very much affected by its position in the mount, cf. Fig. 13 (completely lateral aspect of the valva) and Fig. 14 (valva in a not quite lateral aspect).

Female genitalia (Text-fig. 9) peculiar and highly characteristic, lamella antevaginalis being a cordiform-V-shaped, vividly brown sclerite, with a corrugated surface and edges, and two concavities towards middle; the ostium bursae proper invert-triangular, with fine lateral folds and dark edges of a characteristic shape, as illustrated (Fig. 9). Signum, a small substellate sclerite of usual shape and structure. (Slide no. 2841, allotype).

Japan, Hokkaido, Nukabira, 5.VII.1958, 1 ठં, holotype, gen. no. 2839; Jozankei, 19.VII.1956, 1 \%, allotype, gen. no. 2841; the same locality and date, $2 \hat{\sigma}$ paratypes, gen. nos. 2846 and 2847; Teine, 9.VIII. 1956, 1 ठ̋, paratype, gen. no. 2845 (Toshio Okv). $4 \hat{\sigma}, 1$ o. Holo- and allotype in the Leiden Museum, paratypes in the collection of Mr. T. OKu.

An interesting novel member of the subgenus Bactra, perhaps nearest to robustana Christoph or loeligeri Diakonoff, from Amur, but with the appearance of a gaudy coloured lanceolana.

Bactra (Bactra) graminivora Meyrick 1922 (Figs. 6, 7)

Bactra graminivora Meyrick 1922, Exot. Microl., vol. 2, p. 521 ( $\not \hat{q}$, Bengal). - Fletcher 1932, Life-histories Ind. Microl., ser. 2, p. 24, pl. 14, figs. a-d (biol., food-plants). - Diakonoff 1950, Bull. Brit. Mus., Ent., vol. 1, p. 287, pl. 6, fig. 24, pl. 7, figs. 34, 36 (lectot. select., gen. $\delta$ i illustr.). - Amsel 1958, Beitr. nat. Forsch. S.W. Deutschl., vol. 17, p. 76 (N. Arabia).

Bactra (Bactra) graminivora, Diakonoff 1956, Zool. Verhand., no. 29 , p. 18 , fig. 10.

Bactra cyperana Amsel 1951, Bull. Soc. Sci. nat. Maroc, vol. 31 , p. 68 , fig. 4. ( $\delta$, Morocco). Syn. nov.

Bactra mediterraneana Agenjo 1952, Faunula Lep. Almeriense, p. 99 , pl. 4 , figs. 32,33 , pl. 12 , figs. 6,7 ( $\not \nmid q$, Spain, Almeria). Syn. nov.

Distribution: India, Bengal; ? Kashmir, Shrinagar; Pakistan, Karachi; Northern Arabia; Spain; Morocco. Central Asia, Margelan, Hbh, 1880, 1 ㅇ, gen. no. 1899 (originally recorded by me as furfurana, 1956, p. 12). East Turkestan, Charchui, 10-15 and 23.VI (no year) (J. von RENNENKAMPF), $2 \delta$, gen. nos. 2579 and 2580 , and 7 \%, gen. nos. 2580-2585. (Leiden Museum).

S. W. Afghanistan, Hilmend River, $500 \mathrm{~m}$, Darweshan, Registan Desert, 18.V.1957 (G. EBERT), 3 \%, gen. nos. 2718, 2719, 2733; Herat, $970 \mathrm{~m}, 25 . \mathrm{IV}$. 1956 (H. G. AMSEL), 2 ô, nos. 2743, 2745. N. W. Afghanistan, Korees Duobi, $600 \mathrm{~m}$, near Bala Murghab, 19.V.1956 (H. G. AMSEL), 1 \%, gen. no. 2721. N. Afghanistan, Polichomri, $700 \mathrm{~m}, 28 . \mathrm{V}$. 1956 (H. G. AMSEL), 1 o, 1 \%, gen. nos. 2862 and 2863. E. Afghanistan, Sarobi, $1100 \mathrm{~m}$, 3.VII.1956 (H. G. AMSEL), 1 ठં, gen. no. 2713; 5 \%, 28.VI.1956, 
gen. nos. 2714, 2724, 2725, 2740. (AMsel Collection).

Iran, Shiraz, 4.IX.1940 (E. P. WILtShIRE), 1 , gen. no. 2850. (AMSEL Collection).

Irak, Bagdad, 10.V.1937 (E. P. Wiltshire), 1 \%, gen. no. 2865.

The nice, well-preserved series from Afghanistan, as well as from Turkestan, reveal that this hitherto little known species is strongly variable. The males usually are fuscous, and resemble the European furfurana most. The females are pale ochreous with light greyish hind wings and variably marked fore wings; of these markings mostly only the dark transverse strigulae on costa and dorsum are visible, but sometimes the longitudinal brownish shadow from base to apex is also present just above the middle of wing; two Turkestan specimens possess dark fuscous discal spots: a smaller one in fold beyond 1/4 of wing and a larger, irregularly elongate one, on end of cell.

The male genitalia are identical to those of the Indian examples. The large oval field of the sacculus may slightly vary as to size and shape. The female genitalia (Figs. 6 and 7) of which a photograph was published earlier (1950, Pl. 7, fig. 34) are illustrated here at a larger scale (Figs. 6 and 7) and may be described as follows. Ostium bursae shaped as a fine, hardly traceable ring, only ventral portion of which usually is visible (Fig. 7); this portion is distinctly sclerotized; colliculum is rather abruptly narrowed below the sclerotized portion, hyaline, but apparently rigid; under this rigid portion the membraneous ductus bursae proper begins. Lamella post-vaginalis represented by a series of slightly sclerotized, but not hairy or aciculate, straight folds (in furfurana, a single curved lip-like fold). (Slides figured, 2585 and 2718).

Although I was not able to study the type material of Bactra mediterraneana Agenjo, the nice figure of the male genitalia of this species is so distinct (l.c., Pl. 12, fig. 6), that I do not hesitate to identify mediterraneana with the present species.

Dr. H. G. AmSEL kindly sent me a male paratype specimen of his B. cyperana from Palestine, expressing his surmise that this species might also be the same as graminivora. I had indeed to confirm this.

Furthermore, I was able to confirm the following identifications of the present species in the AMSEL Collection. Iraq, Bagdad, 18.V.1956, ex coll. Wiltshire, $1 \hat{\delta}$, gen. no. 3371 Ams.; North East Arabia, Dhahran, 11.III. 1957, e coll. Talhouk, 1 đo, gen. no. 3340 Ams.; Ras Tanura, 18.IV.1957, the same, $1 \hat{o}$, gen. no. 3346 Ams.

\section{Bactra (Bactra) telaviviana Amstel 1935 (Fig. 5)}

Bactra telaviviana Amsel 1935, Zoogeographica, vol. 2, p. 46, 123 (nom. nud.) - 1935, Mitt. Zool. Mus. Berlin, vol. 20, p. 291, pl. 11, fig. 89 (Tel Aviv, Palestine). - Veröff. Deutsch. Kol. Uebers. Mus., vol. 1, p. 261, no. 230.

Distribution. Palestine.

Dr. AMSEL kindly sent me for closer study the female holotype of this interesting species. I use this opportunity to describe and illustrate, with Dr. AMSEL's consent, the female genitalia for the first time.

Female genitalia (Text-fig. 5). Eighth segment sclerotized, apophyses strong. Sterigma formed by a U-shaped lamella antevaginalis; lamella postvaginalis indicated only by small semicircular folds. Colliculum narrow, long, funnel-shaped, hyaline. Signum apparently absent. (Slide no. 2770).

\section{Bactra (Chiloides) simpliciana Chrétien 1915 (Figs. 12, 18)}

Bactra simpliciana Chrétien 1915, Ann. Soc. ent. France. vol. 84, p. 301 (adult), 302 (larva and pupa; on Cyperus conglomeratus Rottb.). - Amsel 1951 Bull. Soc. Sci. Nat. Maroc, vol. 31, p. 68.

Bactra telaviviana, Amsel 1951 (nec Amsel 1935!), Beitr. nat. Forsch. S.W. Deutschl., vol. 17, p. 76, fig. 18 ( $\not ै$, N.E. Arabia; attrib. subgen. to Chiloides).

Owing to the great kindness of Mr. J. Bourgogne, Muséum National d'Histoire Naturelle, Paris, I was able to study the unique type specimen of the present species. It may be redescribed as follows. of $18 \mathrm{~mm}$. Head with smoothly appressed scales; pale ochreous. Thorax pale ochreous. Palpus moderate, triangularly dilated, rather smooth, except a tuft on upper edge at the top; pale ochreous, median segment suffused with grey externally except on basal third, terminal segment very short, exposed. Abdomen whitish-ochreous.

Fore wing elongate-semioval, almost sublanceolate, dilated, broadest beyond 2/3; costa almost straight, apex distinctly rounded, termen rounded, oblique. Unicolorous very light ochreous, with a slight gloss 


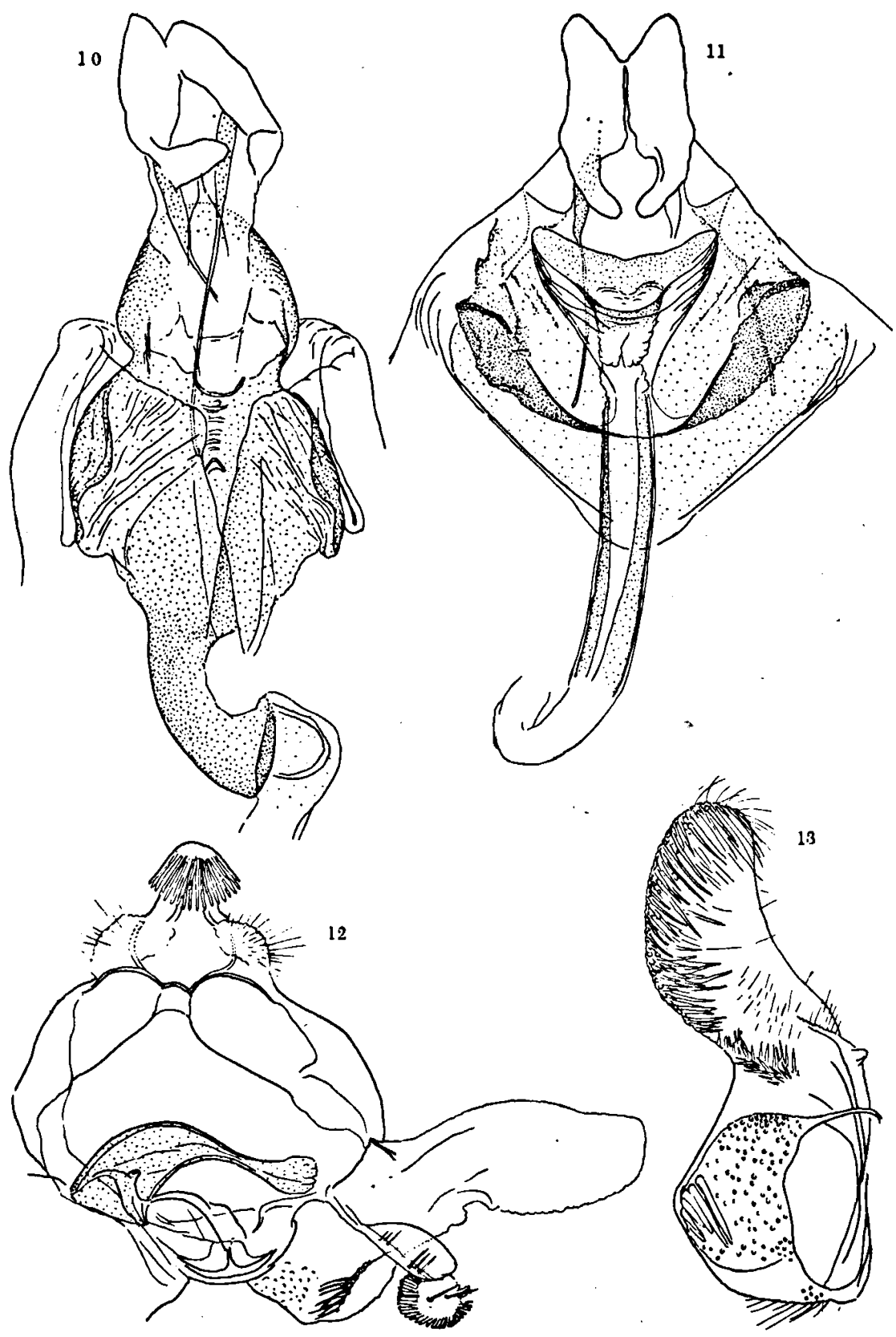

Figs. 10-13. Genitalia of Bactra. 10. B. (Chiloides) diakonoffi Amsel, female, allotype. 11. B. (C.) grethae spec. nov., female, holotype (Pakistan). 12, B. (C.) simpliciana Chrét. (no. 3334, N. Arabia). 13. B. (B.) festa spec. nov., paratype (no. 2845), left valva in lateral aspect

and with a faintest pale tawny tinge; terminal and apical edges narrowly suffused with tawny-brownish. Cilia ochreous-whitish, a faint tawny submedian shade, base pale.

Hind wing whitish, apical fourth faintly suffused with very pale ochreous, suffused with greyish towards apex, with a golden gloss. Cilia white with a faintest yellowish tinge opposite apex and upper half of termen.

Male genitalia (Figs. 12, 18). Socius rather small. 

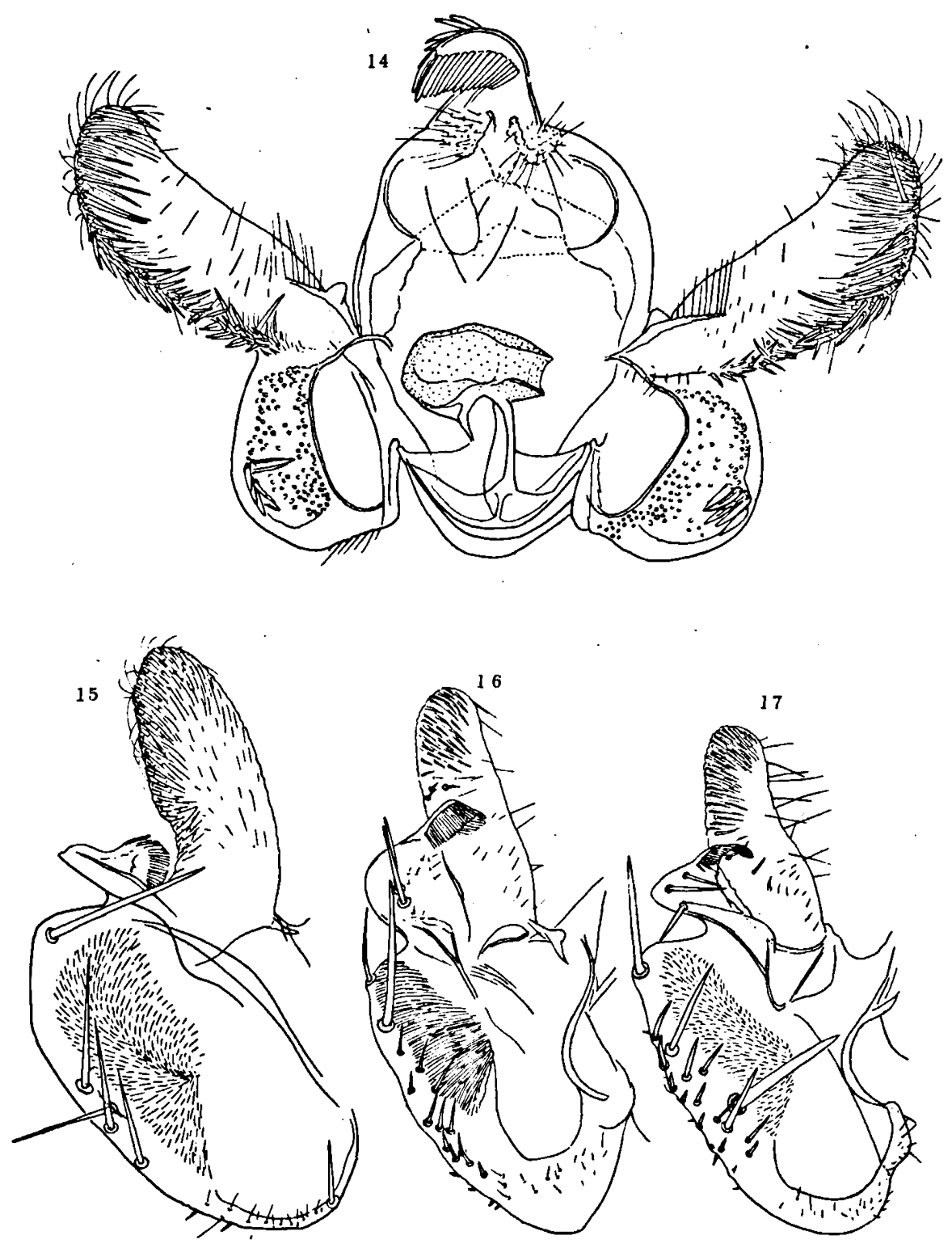

Figs. 14-17. Male genitalia of Bactra. 14. B. (B.) festa spec. nov., holotype. 15-16. Left valva of the types of B. (C.) diakonoffi, Amsel, monochorda Diak., and excelsa Diak., respectively (16 and 17 after DiakonofF 1956)

with uncus resembling those parts in B. furfurana. Valva submembraneous, rather weak, cucullus clothed, except along costa, with fine hairs, not with bristles. Valvula short, the apical bristles ("corona") moderately long; two characteristic bristles on the inner side of the stalk. Sacculus large but rather amorphous, weak, with a big area covered with the characteristic round impressions and with fine short hairs. The stout spines are attached on the external side of the sacculus (as shown in the left valva; in the right the spines are fully drawn for the sake of clarity).

Holotype (monotype), male, gen. no. 2876, with labels: "Cyp. conglom., 26.4.09" in black ink; red label "TYPE"; "Bactra simpliciana" in violet ink. In good condition but with left half of thorax and the basal half of the left fore wing with a brown stain.

The two male specimens, recorded by Dr. AMSEL 
(1958) from Northern Arabia, one of which I was kindly allowed to study, and attributed by him to B. telaviviana (described after a single female) appear to be identical with the above re-described type of simpliciana. Whether simpliciana $(\delta)$ and telaviviana (P) are only sex partners of one and the same species, it is not possible at present to decide. The two names should be kept separate, pending further evidence of bred material. Obtaining of this material of simpliciana seems to be not very difficult, since Curtetien indicated the food plant and the time of occurrence of the larval stages. The present political unrest in the countries of North Africa may delay the solution of this problem for a long time, though. Material studied: $1 \hat{\delta}$, North Arabia, Hofuf, 15.II. 1957, gen. no. 3334 Ams., figured on Text-fig. 12.

This large species with long unicolorous wings with a rounded apex, is of especial interest, for it seems to represent an early form of the subgenus Chiloides, with small sacculus and valvula as compared with the large cucullus.

The types of two species of Bactra, described by Count E. Turati from Cyrenaica, viz., lactosana and pauperrima, were not available to me. Apparently, these types are lost. It is probable that they represent the same species, and are synonyms of simpliciana.

\section{Bactra (Chiloides) straminea (Butler 1881) (Pl., fig. 2)}

Chiloides straminea Butler 1881, Ann. Mag. Nat. Hist., ser. 5, vol. 7, p. 393, no. 23 (Hawaii). - Meyrick 1885, Trans. N. Zeal. Inst., vol. 17, p. 142 (part.). - Walsingham 1907, Fauna Haw., vol. 1, p. 687-688, pl. 11, fig. 5. Diakonoff 1956, Zool. Verhand., no. 29, p. 26, figs. 4, 24-25 (gen. ờ).

Bactra (Chiloides) straminea, Diakonoff 1956, Zool. Verhand., no. 29 , p. 26 , figs. 4 , 24-25 (gen. $\delta$ ' ).

Bactra iomolybda Meyrick 1932, Exot. Microl., vol. 4, p. 224 ( $\hat{O}$, Hawaii). Syn. nov.

A comparison of the genitalia of the type specimen and close study of further material at the British Museum revealed that Bactra iomolybda Meyrick is only a synonym of straminea Butler. The only slight difference between the types which is traceable is a transverse series of additional moderate spines across the inner side of the disc of the saucculus, running beside and parallel to the base of the median coronate appendage of the valva (valvula). This series of spines is indicated in the photograph by an arrow (Pl., fig. 2). By the courtesy of the Trustees of the British Museum (Natural History) I am able to reproduce this photograph, representing the male genitalia of the type specimen of iomolybda. This difference, however, is very slight and occurs in several male specimens from Hawaii studied by me. Tentatively I propose to retain this name as Bactra (Chiloides) straminea Butler forma $\widehat{o}$ iomolybda Meyrick (status nov.).

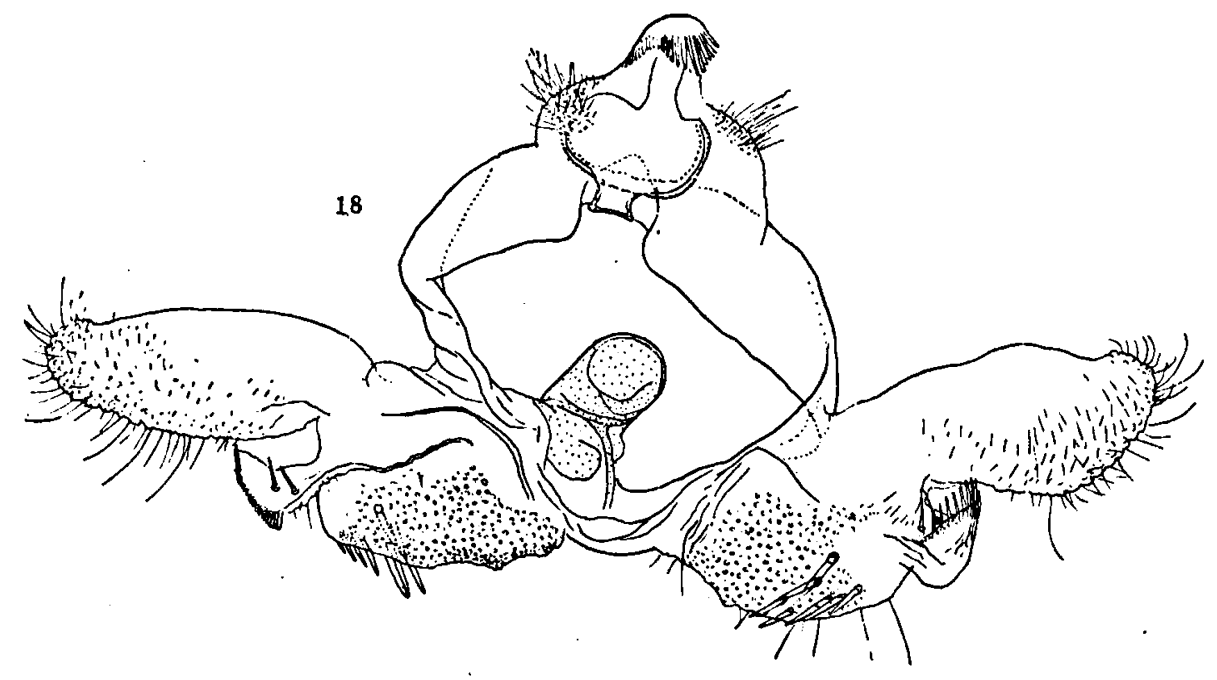

Fig. 18. Male genitalia of Bactra simpliciana Chrét., 'holotype, gen. no. 2876, Paris Museum 


\section{Bactra (Chiloides) venosana (Zeller 1847)}

Phoxopteris venosana Zeller 1847, Isis, p. 738.

Aphelia venosana, Herrich-Schäffer 1849, Syst. Bearb., vol. 4, p. 244.

Bactra venosana, Rebel in Staudinger \& Rebel 1901, vol. 2, p. 113. - Kennel in Spuler 1910, Schmett. Eur., vol. 2, p. 273 . - Kennel 1910, Pal Tortr., p. 472 , pl. 18, fig. 73. Bactra (Chiloides) venosana, Diakonoff 1956, Zool. Verhand., no. 29 , p. 33 , figs. $31-33$ (gen. $\delta$ fig.).

The more material of this species comes to my notice, the closer appears to be its affinity to Bactra (Chiloides) truculenta Meyrick, a widely distributed, tropical species from Southern Asia. In the male the only reliable difference is the size and the number of the spines on the median external portion of the sacculus: these are much longer and more robust, but less numerous in truculenta. The females, however, are clearly different (cf. my Figs. 28-32, 1956).

Identifications confirmed. Palestine, Jericho, Lichtfang, 31.V.1930, $1 \delta$, gen. no. 2816; Tabgha, Tiberias, 10.V.1930, 1 $\delta$, gen. no. 2815 (H. G. AMSEL). Jordan Valley, Zerqa R. Colony, c. $100 \mathrm{~m}$ below sea level, at light, 25.VI.1954 and 22.IX.1954 (Trevor Trought), $2 \%$, gen. nos. 2819 and 2821. Sardinia, Porto Santoru, 12.VI.1936 (H. G. AMSEL), 1 ô, 1 ᄋ, gen. nos. 2817 and 2805. Tempis, 6.V.1932, 1 ठิ, gen. no. G.U. 92, Amsel (H. G. AMSEx). (AMSEL Collection).

\section{Bactra (Chiloides) truculenta Meyrick 1909 (Pl., fig. 4)}

Bactra truculenta Meyrick 1909, J. Bombay Nat. Hist. Soc., vol. 19, p. 586 ( $\delta$, India). - Diakonoff 1950, Bull. Brit. Mus., Ent., vol. 1, p. 289 , pl. 5 , fig. 16, pl. 7, fig. 30 (lectotype select., syn. scythropa and geraropa).

Bactra scythropa Meyrick 1911, Proc. Linn. Soc. N.S Wales, vol. 36, p. 284 (O Timor, Dilli).

Bactra geraropa Meyrick 1932, Exot. Microl., vol. 4, p. 147 ( $Q$ Formosa).

Bactra (Chiloides) truculenta, Diakonoff 1956, Zool. Verhand., no. 29 , p. 27, figs. 28-30 (gen. $\delta \propto$ re-descr., fig.).

Distribution. India, Ceylon, Andaman Islands, South China, Formosa, Timor, Hawaii, Australia?, Fiji?. Known to me previously from India, Java, Borneo, Kisar Island, Philippine Islands, Hawaii,
Caroline Islands.

One male specimen, from Mauripur, clearly shows a peculiarity of the genitalia which apparently is always present but not always as clearly visible as in this case; therefore I present a photograph of these genitalia (Pl., fig. 4). This photograph shows a kind of sclerotized rounded cap over the top of the sacculus (between arrows). This structure is omitted from my previous figures (1956, figs. 29,30 ). It is equally present in venosana.

Pakistan, Mauripur, 29.VII.1956, at light, 2 o, gen. nos. 2129 and 2131. Thailand, Bangkok, 2127.XI.1957, 1 \%, gen. no. 2439, 1 o, gen. no. 2440; Keng Phen Dao, 8.XII.1957, 1 \%, gen. no. 2443 (L. D. BRoNGERSMA). $3 \delta, 2$ ㅇ.

\section{Bactra (Chiloides) diakonoffi Amsel 1958 (Figs. 10, 15)}

Bactra (Chiloides) diakonoffi Amsel 1958, Beitr. nat. Forsch. S.W. Deutschl., vol. 17, p. 76, f. 19 ( $\delta$,, N. Arabia, $\hat{\sigma}$ gen. illustr., attrib. to subg. Chiloides).

Owing to the kindness of Dr. Amsez I had an opportunity to examine the holotype and the allotype specimens of this recently described species, and also was kindly granted permission to figure the genitalia at somewhat larger scale than in the original figure.

The species is very close to the tropical Asiatic excelsa Diak. and monochorda Diak., as Text-figs. 15-17 show, but sufficiently distinct from both. The differences of the males are the shape and the armature of the sacculus. In diakonoffi it is broader and larger, armed with some six large marginal spines only, gently decreasing in size proximad. Furthermore the cucullus is slightly broader, and the valvula is without the bristles along the stalk. (That the corona of the valvula is absent, as stated in the description, is a delusion). (Slide no. 3339 , Ams.).

The allotype proves to be equally related to $e x$ celsa, but also to be distinct. I have no doubt that the types are sex partners indeed. The differences from the female genitalia of excelsa are as follows. Eighth tergite (Text-fig. 10) erect-oval, instead of almost circular, as in excelsa; lamella antevaginalis less broad, with upper angles folded over, and with lower (distal) portion differently shaped, without a split; colliculum distinctly shorter. (Slide no. 2771, Diak.). 
Bactra (Chiloides) grethae spec. nov. (Fig. 11)

\$ $16 \mathrm{~mm}$. Head, palpus and thorax (rather rubbed) pale ochreous, palpus moderate, rather slender, terminal segment infuscated. Abdomen pale ochreous.

Fore wing (rubbed) pale ochreous, irrorated with fuscous, brown-fuscous suffusion in disc before and beyond cell, connected with a more or less distinct, interrupted row of cloudy brownish-fuscous marks on terminations of veins. (Cilia lacking).

Hind wing ochreous-whitish, faintly irrorated with pale fuscous or greyish, more distinctly so towards apex. Cilia whitish.

Female genitalia (Text-fig. 11) with sterigma complicated and characteristic. Eighth sternite membraneous, with a broad split in middle in which fits a broad, funnel-shaped and sclerotized, enlarged ostium bursae, plicate at the sides; below this the sternite with two elongate-oval, sublateral, heavily sclerotized plates, narrowed and united mesially Colliculum well-developed, straight and rather long Signum, a rather large substellate sclerite of usual shape and structure. (Slide no. 2130, holotype).

Pakistan, Mauripur, 29.III.1956, at light, 1 , holotype, gen. no. 2130 (L. D. Brongersma). Unique. Dedicated to the wife of the collector, Dr. M. BronGERSMA-SANDERS.

The specimen is rather rubbed, but the genitalia are so distinct that I do not hesitate describing this new species. I expect the, so far unknown, male to possess a long and sclerotized aedoeagus, in accordance with the long colliculum of the female. At present I am not able to indicate the affinity of this interesting species, pending the discovery of the male.

\section{Bactra (Chiloides) leucogama Meyrick 1909}

Bactra leucogama Meyrick 1909, J. Bombay Nat. Hist. Soc., vol. 19, p. 584 (Ceylon, ôㅇ) - - Diakonoff 1950, Bull. Brit. Mus., Ent., vol. 1, p. 287, pl. 6, fig. 22, pl. 7, fig. 33.

Bactra (Chiloides) leucogama, Diakonoff 1956, Zool. Verhand., no. 29 , p. 45 , figs. $39-41$.
Distribution. Ceylon, Celebes.

Thailand, Keng Phen Dao, 8.XII.1957, 1 , gen no. 2442 (L. D. Brongersma). 1 specimen.

Bactra (Nannobactra) leonina spec. nov. (Fig. 8)

$14 \mathrm{~mm}$. Head, thorax ochreous-whitish. Palpus triangularly dilated, apex of median segment produced into an acute point, terminal segment concealed; whitish, basal and lower edge of apical half, suffused with black. Abdomen whitish-ochreous.

Fore wing sublanceolate, rather narrow, costa abruptly curved at base, slightly curved throughout posteriorly, apex pointed, termen oblique, gently convex. Pale ochreous-yellowish (rather rubbed), faintly suffused in disc, along termen, and in apex upward as far as vein 8 , with grey; a continuous series of very short, blackish-brown strigulae alternating with points along costa, and a series of marginal short blackishbrown strigulae along termen. Cilia dull sordid ochreous-whitish, base narrowly white; faintly barred with fuscous, bar opposite apex distinct, dark grey.

Hind wing glossy fuscous-grey, semipellucent to- wards base, towards apex becoming dark grey and opaque. Cilia ochreous-whitish, with a subbasal grey shade.

Female genitalia (Text-fig. 8) resembling those of minima Meyrick. Sterigma, a minutely aciculate cup, much larger than in that species, upper angles also slightly produced, lateral walls much thicker; lower rim or lip, similar. Ninth segment more sclerotized throughout, anapophyses straight, sclerotized and longer (in minima, not sclerotized, curved). Signum of usual shape and structure: a moderate, cup-shaped minutely aciculate sclerite, stronger sclerotized than in minima. (Slide no. 2441).

Thailand, Bangkok, 24-27.XI.1957, at light, 1 q, holotype, gen. no. 2441 (Leo D. Brongersma). Unique. Nearest to Bactra (N.) minima Meyrick, differing by the genitalia.

Bactra (Nannobactra) phaulopa Meyrick 1911

Bactra phaulopa Meyrick 1911, Proc. Linn. Soc. N.S. Wales, vol. 36, p. 253 (ใ, Kei Islands). - Diakonoff 1950,
Bull. Brit. Mus., Ent., vol. 1, p. 288, pl. 8, fig. 42 (gen. descr., fig.). 
Bactra (Nannobactra) phaulopa, Diakonoff 1956, Zool. Verhand., no. 29 , p. 52 , figs. 50,51 (gen. $\delta \hat{q}$ redescr., fig.).

Correction. Unfortunately, on p. 55 of the above cited paper (1956), references in the text to the figures of the genitalia of this species on the opposite page got interchanged: fig. 50 refers, of course, to the female, fig. 51 , to the male.

\section{Bactra (Nannobactra) minima Meyrick 1909}

Bactra minima Meyrick 1909, J. Bombay Nat. Hist. Soc., vol. 19 , p. 586 ( $₫$, Barberyn Island, Ceylon). - Diakonoff 1950, Bull. Brit. Mus., Ent., vol. 1, p. 288, pl. 6, fig. 25 (lectot. select., gen. ô fig.).

Bactra (Nannobactra) minima, Diakonoff 1956, Zool. Verhand., no. 29, p. 55, figs. 52-53 (syn. phaeopis, gen. $\delta$ 오 redescr., fig.).

Bactra phaeopis Meyrick 1911, Proc. Linn. Soc. N.S. Wales, vol. 36, p. 254 ( $\delta$, Sudest Island, N. Guinea). Diakonoff 1950, Bull. Brit. Mus., Ent., vol. 1, p. 288, pl. 6, fig. 28 (gen. $\hat{o}$ ), pl. 8 , fig. 41 (gen. $\&$ ). (Lectot. select., gen. $\hat{o}$ 오 descr., fig.). - 1956, Zool. Verhand., no. 29, p. 55.

Bactra microtripta Meyrick 1927, Ins. Samoa, vol. 3, Lep., fasc. 2, p. 75 ( $\delta$, Samoan Islands). Syn. nov.
A close comparison of the types of minima and microtripta in the British Museum (Natural History) proved to me that they are the same species.

It should be noted that the edge of the valva of this species is armed not with a single series but with several series of stout spines which are arranged closely to one another and make the impression of being a single dense row of spines, as in Fig. 53 of my above cited revision (1956).

\section{"Bactra" roseana Walsingham 1900}

Bactra roseana Walsingham 1900, Ann. Mag. Nat. Hist., ser. 7, vol. 6, p. 334 ( $\hat{\partial}$, Japan).

This large, elegantly coloured and marked species from Japan has nothing whatever to do with the genus Bactra, but belongs to the tribe Olethreutini and might be placed somewhere near the genus Olethreutes. I studied the male type specimen at the British Museum (Natural History).

\section{POSTSCRIPT}

Shortly before this paper was sent to the printers', Dr. S. Toll, Katowice, Poland, kindly sent me his just appeared interesting paper on some new Tortricidae (Drei weitere neue Arten der Familie Tortricidae aus Polen, Ann. zool., vol. 17, pp. 65-80, pl. 2-5, 16 text-figs., Warszawa, 1958). In this paper a new Palaearctic Bactra species, $B$. gozmanyana, is described. I do not venture to make any comments upon this species, before a close study of Dr. ToLL's material which he very kindly promised to send me. 